\title{
Pearson syndrome
}

INSERM

\section{Source}

INSERM. (1999). Orphanet: an online rare disease and orphan drug data base. Pearson syndrome. ORPHA:699

Pearson syndrome is characterized by refractory sideroblastic anemia, vacuolization of bone marrow precursors and exocrine pancreatic dysfunction. 